\title{
Clemens Alexandrinus Epistularum Ioannis apostoli interpres*
}

Jana Plátová

Je známou skutečností, že Klement z Alexandrie ve svém díle přímo cituje $\mathrm{z}$ více než 360 různých autorů. Neplatí přitom přímá úměra: čím větší počet citací, tím větší autoritu Klement příslušnému zdroji přisuzuje. Annewies van den Hoek ve svém článku z 90. let, v němž analyzuje způsob, jak Klement jednotlivé autority uvádí, přesvědčivě dokázala, že kromě přiznaných více či méně volných citací existuje v Klementově díle řada výpůjček, jejichž zdroj Klement často neuvádí právě u autorů, na něž bezprostředně navazuje a kteří v jeho teologické koncepci hrají klíčovou roli. ${ }^{1}$ Ve světle tohoto zjištění se tedy nabízí domněnka, že knihy Nového zákona sepsané pod jménem apoštola Jana jsou pro Klementovo myšlení důležitější, než se na první pohled může zdát, a to přesto (nebo právě proto), že nepatří k nejcitovanějším.

\section{Klementova znalost Janovích listů}

Klement znal pravděpodobně všechny tři listy, které se později staly součástí novozákonního kánonu, i když ve svém díle př́mo cituje pouze z prvního. ${ }^{2}$ Víme však, že i Druhý list Janưv Klement znal a měl k dispozici, když se ho rozhodl spolu s dalšími biblickými knihami komentovat ve svém díle Hypotypóseis. Tento spis (nebo snad přípravný materiál pro pozdější dílo?) byl naposledy spatřen v sedmdesátých letech 18 . století

* Studie byla připravena za finanční podpory GAČR prostřednictvím grantu Historie a interpretace Bible, č. P401/12/G168.

1 A. van DEN Hoek, „Techniques of Quotation in Clement of Alexandria: A View of Ancient Literary Working Metods," VigChr 50 (1996): 223-243.

2 V Klementově době lze kánon novozákonních knih považovat ještě za otevřený; k tomu srov. můj článek „,Taková tajemství, jako je Bůh, lze svěřit Slovu, nikoli spisům': Novozákonní kánon a apokryfy podle svědectví Klementa z Alexandrie, " Studia theologica 24 (2006): 1-15, zvl. s. 4-7. 
v klášteře sv. Makaria v Egyptě. ${ }^{3}$ Podle Eusebia měl být osmisvazkovým komentářem k vybraným veršům Písma, včetně knih „pochybných“ ( $\tau \dot{\alpha}$ $\dot{\alpha} \nu \tau \iota \lambda \epsilon \gamma o ́ \mu \epsilon \nu \alpha)$, jako např. Listu Judova a ostatních katolických epištol, ale také Listu Barnabášova nebo Petrovy apokalypsy. ${ }^{4}$ Dochovalo se nám z něj však pouze 24 krátkých řeckých zlomků obsahujících komentář k několika veršům evangelií, Skutků a Pavlových listů (Rím, 1 a 2 Kor, Gal, Žid, 1 a 2 Tim), a dále delší zlomek s latinským překladem Klementova textu, který nechal v 6. století pořídit Cassiodorus Senator; tento text, který je dochován ve třech rukopisech pod názvem Adumbrationes, obsahuje Klementovy poznámky k listům 1 Petr, Jud, 1 a 2 Jan.

Svědectví tohoto latinského textu patrně nebere $\mathrm{v}$ úvahu Bruce M. Metzger, který Druhý list Janưv uvádí mezi listy, které Klement necituje. ${ }^{5}$ Nicméně i kdybychom existenci Adumbrationes nebrali vážně, at' už pro pozdní vznik jejich latinské verze, nebo z nějakého jiného důvodu, jistě bychom neměli přehlédnout Klementovu formulaci ve Strom. II,66,4, jíž zde uvádí citát 1 Jan 5,16-17: „Zdá se, že i Jan ve svém větším

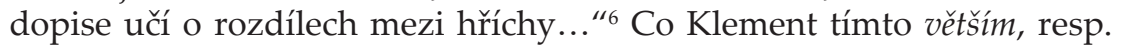

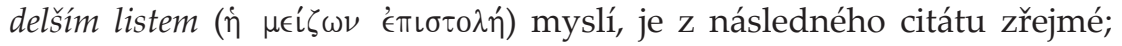
označení Proního listu Janova jako delšího listu však předpokládá - alespoň při běžném komparativním užití adjektiva, které vyžaduje předmět srovnání - znalost nějakého jiného, kratšího listu, tedy pravděpodobně Druhého nebo dokonce Třetího listu Janova. Poslední Janův list Klement nikde necituje ani nekomentuje. To však nemusí nutně znamenat, že ho neznal či nepřijímal; nepř́tomnost citací tak krátkého textu, jakým je Třetí list Januv, může být také dílem náhody (podobně jako v případě Listu Filemonovi).

3 Srov. F. E. Osborn - C. Ducкworth, „Clement of Alexandria's Hypotyposeis: A French Eighteenth-Century Sighting, “ JThS, N.S., 36 (1985): 67-83; F. E. Osborn, „Clement's Hypotyposeis: Macarius revisited," SecCent 10 (1990): 233-235.

4 Srov. Eusebios, Hist. eccl. VI,13,2 a VI,14,1. Srov. ale také pozdější svědectví Fótiovo, Bibl. 109, který hovoří o komentáři ke Gn, Ex, Žl, k Pavlovým listům a ke knize Kazatel:

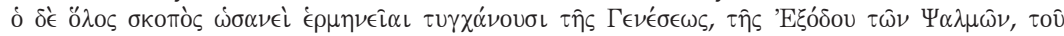

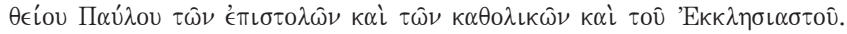

5 Srov. B. M. Metzger, The Canon of the New Testament, Oxford: Oxford University Press, 1987; citujeme z německého překladu: Der Kanon des Neuen Testaments. Entstehung, Entwicklung, Bedeutung, Düsseldorf: Patmos 1993, s. 132: „Mit Ausnahme des Philemonbriefs, des Jakobusbriefs, des 2. Petrusbriefs und des 2. und 3. Johannesbriefs finden sich bei Clemens Zitate aus allen Büchern des Neuen Testaments."

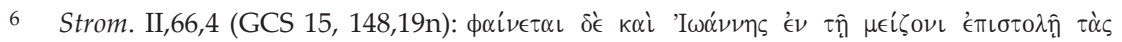

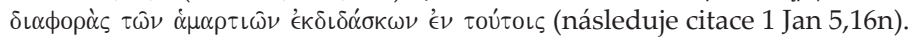




\section{Klementův vÝKlad PrvníHo a Druhého listu Janova:}

ADUMBrationes

V osmé kapitole svých Institutiones Cassiodorus poznamenává, že nám Klementovo učení předkládá $\mathrm{v}$ očištěné podobě, protože $\mathrm{v}$ některých př́padech hovořil Klement přiliš neopatrně. Protože Cassiodorus některé pasáže nepovažoval za dostatečně ortodoxní, prý je prostě vyškrtl, aby nás uchránil. ${ }^{7}$ Otázka je, zda překladatel ke Klementovu komentáři také něco nepřidával. Překladatelovu věrnost originálnímu znění dosvědčují naopak hned tři skutečnosti: v prvé řadě několik obsahových paralel se zlomky spisu Hypotypóseis dochovanými u Eusebia, dále celkový styl komentáře, který odpovídá Klementovým fragmentům dochovaným u ps.-Oikúmenia (i tam se jedná o kratší vysvětlující poznámky k vybraným novozákonním veršům nebo jen $\mathrm{k}$ jejich interpretačně obtížným částem), a do třetice řecký fragment komentáře $\mathrm{k} 1$ Jan 2,3, který ukazuje na doslovnost latinského překladu. ${ }^{8}$

Klementův výklad postupuje po jednotlivých verších, ale ke komentáři si vybírá pouze 43 z celkového počtu 105 veršů (tedy ani ne polovinu). ${ }^{9}$ Jedná se o verše, které se jeví našemu autorovi zajímavé, dưležité nebo pro něj představují z interpretačního hlediska určitý problém. Některé verše komentuje důkladně, ale u většiny se jen zastaví s krátkou vysvětlující poznámkou. Ze čtvrté kapitoly např. vybírá pouze 18. verš. S oblibou odkazuje na jiné verše Písma, jimiž př́slušné pasáže ozřejmuje. Nápadná je absence odkazů na nekřestanské autority, což tento text na první pohled odlišuje od trojice Klementových děl Protreptikos, Paidagógos a Strómata.

Začátek prvního verše Proního listu Janova („,to, co bylo na počátku, co jsme slyšeli, co jsme na vlastní oči viděli...") spojuje Klement se začát-

7 Srov. Cassiodorus, Institutiones I,8,4: „In epistolis autem canonicis Clemens Alexandrinus presbyter, qui et Stromatheus vocatur, id est in epistula sancti Petri prima, sancti Ioannis prima et secunda et Iacobi quaedam Attico sermone declaravit; ubi multa quidem subtiliter, sed aliqua incaute locutus est; quae nos ita transferri fecimus in Latinum, ut exclusis quibusdam offendiculis purificata doctrina eius securior potuisset hauriri." Uvedení Jak místo Jud, jehož komentář se ve skutečnosti v rámci Adumbrationes dochoval, bývá považován za pouhý lapsus linguae.

8 Srov. Adumbr. III (GCS 17, 212,3-6). Vzhledem k délce tohoto textu (pouhé 3 řádky) je však jeho výpovědní hodnota poměrně malá.

9 Jedná se o tyto verše: 1 Jan 1,1.2.5.7.10; 2,1-3.5.7-10.12-17.18.20.22.23.28.29; 3,1.2.8-10. .12.15.16.20.21.24; 4,18; 5,6-8.14.19.20. 
kem Janova evangelia („na počátku bylo Slovo“) a rozvíjí na tomto základě úvahu o preexistenci Slova. Výraz „na počátku“ užitý jak v Janově evangeliu, tak v Proním listě Janově podle něj ukazují jednak na nerozdělitelnost božských osob, jednak na nerozlučitelnost božsko-lidské přirozenosti Ježíše Krista. Zatímco prolog Janova evangelia hovoří o Slovu a jeho bytí s Otcem před jeho vtělením, začátek Proního listu Janova odkazuje na vtělené Slovo, které se stalo dosažitelné lidem. ${ }^{10}$ Za problematickou bývají označovány formulace, jimiž Klement, nebo spíše autor překladu, dále popisuje vztah mezi Slovem a Otcem. Minimálmě výraz „shodné podstaty" (secundum aequalitatem substantiae unum cum patre subsistit) ${ }^{11}$ považují někteří badatelé za pozdní interpolaci, protože užití tohoto speciálního teologického termínu na přelomu 2. a 3. století není velmi pravděpodobné. ${ }^{12}$

Celý výše zmíněný výklad uvozuje Klement slovy „presbyter vysvětloval“; ${ }^{\text {"13 }} \mathrm{z}$ textu samotného přitom není jasné, kdo je oním presbyterem, a tedy i autorem následujícího výkladu, zda sám apoštol Jan, nebo někdo jiný. V úvahu by připadal Klementův učitel Pantainos, na jehož osobu se Klement výslovně odvolává pouze jednou, a to v Eclogách. ${ }^{14} \mathrm{Z}$ ostatních míst, kde je jeho osoba pravděpodobně míněna, ${ }_{1}^{15}$ je jako „presbyter" označen pouze v pasáži citované u Eusebia (zlomek ztracených Hypotypóseis). ${ }^{16}$ Pro osobu apoštola Jana by naopak hovořila skutečnost, že Jan je jako „presbyter“ opakovaně označován v Klementově kázání Quis dives salvetur?, jehož závěrečná pasáž se však dochovala rovněž pouze u Eusebia. ${ }^{17}$ Na přesvědčivosti jednomu či druhému řešení ubírá fakt,

10 Srov. Adumbr. III (GCS 17, 209,24-210,9).

11 Adumbr. III (GCS 17, 210,5-6).

12 Srov. Chr. Markschies, ,,'Die wunderliche Mär von zwei Logoi...' Clemens Alexandrinus, Frgm. 23 - Zeugniss eines Arius ante Arium oder des arianischen Streits selbst?” in Logos: FS für Luise Abramowski (BZNW 67), ed. H. C. Brennecke et al., Berlin: De Gruyter, 1993, s. 213, pozn. 116; M. J. Edwards, „Clement of Alexandria and his Doctrine of the Logos," VigChr 54 (2000): s. 172, pozn. 35.

13 Adumbr. III (GCS 17, 210,1): hoc modo presbyter exponebat.

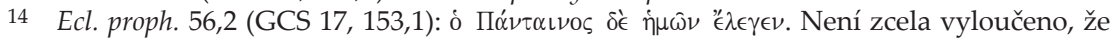
text dochovaný pod názvem Eclogae propheticae představuje první část ztracených $H y$ potypóseis; $\mathrm{k}$ této hypotéze srov. P. NAutin, „La fin des Stromates et les Hypotyposes de Clément d'Alexandrie," VigChr 30 (1976): 268-302.

17 QDS 42,4.9 (GCS 17, 188,14n.15; 189,15; in Eusebios, Hist. eccl. III,23,6-19). 
že Eusebius, jenž je v obou př́ípadech jediným svědkem textu, nebývá považován za spolehlivý zdroj.

Neméně zajímavý je výklad druhé části verše, totiž slov „naše ruce se dotkly Slova života“. V něm Klement popisuje, jak se Jan dotýká „vněj-

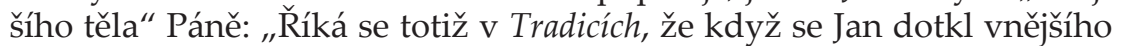
těla [Páně], jeho ruka se do něj hluboko ponořila, aniž by narazila na jakýkoli odpor, naopak jeho tělo přijalo ruku učedníka. “18 Do jisté míry podobné vyprávění najdeme v apokryfních Skutcích Janových: „Občas, když jsem ho chtěl uchopit, jsem narazil na hmotné a tuhé tělo. Jindy zas byl na dotyk úplně nehmotný, jako by neměl tělesnou podstatu a prostě vůbec nebyl. ${ }^{\prime 19}$ Pokud bychom Klementem uvedený výklad chápali jako citaci či parafrázi Skutku Janových, znamenalo by to, že vznik tohoto apokryfního spisu musíme klást již do druhého století. ${ }^{20}$ Rozhodující je, jak pochopíme formulaci, kterou Klement historku uvádí: slova „fertur

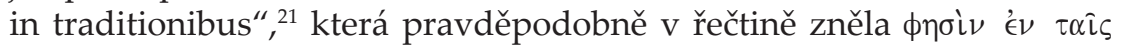

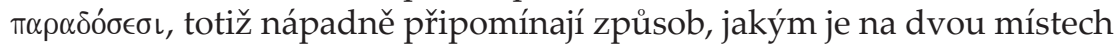
ve Strómatech uvozován spis Matějovy tradice. ${ }^{22}$ Odkazuje tato formulace na konkrétní literární dílo? Pravděpodobnější, než že by Klement citoval ze spisu, který je nám znám jako Skutky Janovy, se jeví řešení, které navrhuje Annewies van den Hoek, že totiž příběh, který Klement použil, mohl být součástí nějaké rané sbírky obsahující vyprávění o životě jednotlivých apoštolů, která se až později stala základem pro jednotlivé apokryfní Skutky. ${ }^{23}$

18 Adumbr. III (GCS 17, 210,12-15).

19 Skutky Janovy 93 (čes. překl. in Příběhy apoštoli̊: Novozákonní apokryfy II., ed. Jan A. Dus a P. Pokorný, Praha: Vyšehrad, 2003, s. 300). Jak upozorňuje J. Dus tamtéž, odlišná, a přece podobná historka se nachází rovněž v Druhém zjevení Jakubově, kde Ježíš vybízí Jakuba, aby se ho dotkl; Jakub napřáhne ruku do prázdna a zmocní se ho úžas a radost (Druhé zjevení Jakubovo, NHC V/4, 57,10).

20 Dus se domnívá, že v př́ípadě Adumbrationes ,jde o tvrzení formulačně př́liš vzdálené dochovanému textu Skutků Janových, než aby bylo možno tuto pasáž z Klémenta chápat jako jeho citaci“ (tamtéž, s. 273). Na tomto místě je třeba si znovu uvědomit, že pozdní latinský překlad nemusí odpovídat řeckému originálu.

21 Adumbr. III (GCS 17, 210,12n).

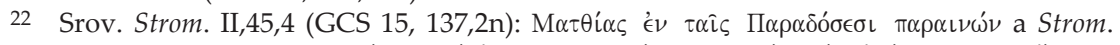

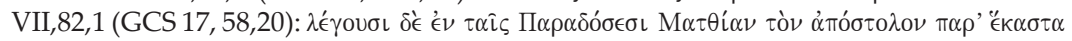

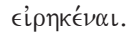

23 Srov. A. van DEN Hoek, "Clement and Origen as Sources on „Noncanonical“ Scriptural Traditions during the Late Second and Earlier Third Centuries," in Origeniana sexta: Origène et la Bible/Origen and the Bible, ed. G. Dorival et A. Le Boulluec, Leuven: University Press 1993, s. 108. 
Komentář k dalším veršům není už zdaleka tak zevrubný. Postupuje podle vybraných veršů např́č celým listem a sleduje jeho základní soteriologickou koncepci. Výchozím bodem, vypovídajícím o Božím milosrdenství, velkorysosti a mírnosti, jsou slova „Bủh je Světlo“ (1 Jan 1,5) a „Bůh je Láska“ (1 Jan 4,16). ${ }^{24}$ Od druhé kapitoly pak za pomoci janovských opozit (světlo - temnota; chodit v pravdě - být lhářem; synové Boží - synové dábla) staví do protikladu dobrovolnou volbu spravedlivých a soudy, jež čekají na zarputilé hř́šníky. ${ }^{25}$ Zdá se, že Klementův komentář $\mathrm{v}$ tomto místě počítá s paralelním výkladem $\mathrm{k}$ Listu Judovu, jehož latinský překlad se rovněž dochoval v rámci Adumbrationes. ${ }^{26}$

Z Druhého listu Janova si Klement vybírá ke komentáři pět z celkového počtu třinácti veršůu, ${ }^{27}$ přičemž největší pozornost věnuje veršům 10 a 11 , nabádajícím k opatrnosti v kontaktu s hříšníky. Celkový rozsah tohoto textu je sotva desetina toho, co představuje komentář k Pronímu listu Janovu.

\section{Ostatní místa, na nichž Klement První list Janův Cituje}

Kromě vlastního komentáře $\mathrm{k}$ vybraným veršům obou listů Klement na několika místech svého díla Proní list Janưv v různých souvislostech cituje. Jedná se o sedm pasáží s celkem 16 citacemi:

\subsection{Paid. III,82,1 s citacemi 1 Jan 4,7 a 5,3}

První citace pochází ze třetí knihy Paidagóga, kde Klement představuje křestanský životní styl. Začínajícím křestanům udílí rady, jak mají vyjadřovat sympatie blízké osobě, aby i takové vnější jednání, jako je např. objetí nebo polibek, vyjadřovalo dobrotu ducha skrývající se uvnitř. I polibek, stejně jako jakékoli jiné lidské jednání, nelze a priori Adumbr. II (GCS 17, 206,26-209,21). Soteriologickou stránkou Klementova komentáře tových exegetických dílech," in Antické křestanství: Liturgie, rétorika, antropologie, ed. V. Hušek, P. Kitzler a J. Plátová, Brno: CDK, 2009, s. 144-149. 
považovat za něco morálně dobrého nebo špatného: polibek může být nečistý, ale i čistý, resp. duchovní ( $\mu$ kazuje Klement jednak na závěrečnou výzvu apoštola Pavla v Řím 16,16 („pozdravte jedni druhé svatým políbením“), jednak si bere na pomoc dva verše ze 4. a 5. kapitoly Proního listu Janova: polibek křestana by měl být vyjádřením "lásky, která je z Boha," parafrázuje Klement 1 Jan 4,7; přičemž Boží láska nespočívá v tom, že se k sobě „lísáme ústy“ ( $\sigma \alpha i v \omega \mu \in \nu$

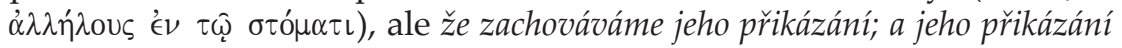
nejsou těžká, cituje Klement 1 Jan $5,3^{29}$ a pokračuje radami, jak má vypadat objímání zamilované dvojice na veřejnosti.

\subsection{Paid. III,98,2-3 s citací 1 Jan 2,2-6}

Druhý citát je součástí závěrečného poselství téhož Paidagóga, který Klementovými ústy vybízí své posluchače, kteří jsou již dostatečně „,vychováni“", aby ve škole, jíž je církev, otevřeli svůj sluch jedinému skutečnému Učiteli, jenž je bude učit božským výrokům. Svou výzvu vstoupit do učení k tomuto Mistru podpírá Klement autoritou apoštola Jana, který ve svém listě hovoří jednak o Kristově oběti za lidské hříchy (1 Jan 2,2), jednak o podmínkách Božího poznání (1 Jan 2,3-6). ${ }^{30}$ Janův text je zde uveden v plném znění, což u delších citací není obvyklé. ${ }^{31}$ Důvodem se zdá být gradace $\mathrm{v}$ závěru celého spisu; citaci přítomnou na jednom z nejexponovanějších míst svého díla uzavírá Klement zvoláním đ” $\tau \eta ̄ \varsigma$ $\mu \alpha \kappa \alpha \rho i ́ o v ~ \theta \rho \epsilon ́ \mu \alpha \tau \alpha \alpha \alpha \iota \delta \alpha \gamma \omega \gamma i \alpha \varsigma$ (,ó děti blažené výchovy“), ${ }^{32}$ aby vzápětí zakončil své dílo chvalozpěvem na Logos.

\footnotetext{
28 Srov. Paid. III,81,2-4 (GCS 12, 281,3-15, zvl. 9).

301 Jan 2,2-6 (in Paid. III,98,2-3; GCS 12, 289,29-290,2).

31 Srov. krácení delších biblických citací na těchto místech: Paid. I,90,1 (GCS 12, 142,29-31); Strom. II,5,1; 12,2; 42,3; 69,3; 83,2; 102,5; 135,4; 136,2; III,3,4; 11,2; 28,6; 75,3; 80,$1 ; 107,3 ; 108,1 ;$ IV,15,4; 164,1; V,74,5 (GCS 15, 115,11n; 119,14; 135,14; 150,4n; 156,15n; 169,$14 ; 188,1-11 ; 197,2 ; 200,25-27 ; 209,14-16 ; 229,34 ; 232,6 ; 246,1.14 ; 255,18-20 ; 321,13 n$; 376,12n); Strom. VII,84,3; Exc. Theod. 62,1 (GCS 17, 60,16; 128,1n). 


\subsection{Strom. I,173,6 s citací 1 Jan 3,14}

Další místo, kde je Proní list Janưv citován, se nachází v závěru první knihy Strómat, kde Klement nastiňuje křestanskou cestu dokonalosti: z pozice služebníka či otroka je křest̉an skrze Zákon vychováván k svobodnému vztahu Božího synovství, přičemž tento přerod je vyjádřen právě janovským "přejít z temnoty do života“. ${ }^{33}$ Část verše 1 Jan 3,14 zde Klement uvádí v rámci své vlastní formulace, aniž by upozornil, že se jedná o citát. Biblický text citoval zřejmě zpaměti, tím lze také vysvětlit záměnu za původní „přejít ze smrti do života“. V bezprostřední blízkosti 1 Jan 3,14 odkazuje Klement v narážkách na řadu dalších starozákonních i novozákonních veršů; doslovně cituje 1 Petr 4,8 .

\subsection{Strom. II,66,4-5 s citací 1 Jan 5,16-17}

Proní list Janưv je výslovně citován také v patnácté kapitole druhé knihy Strómat, která je věnována hamartologii. Klement v ní rozlišuje tři stupně zlého jednání: omyl jako bezděčný hřích, hřích jako nechtěný zločin a zločin jakožto úmyslné zlo. ${ }^{34}$ Toto rozlišení posléze dokumentuje celou škálou biblických výroků, jimiž chce připomenout milosrdenství dobrého Boha: ̌̌ím 6,14; Iz 53,5; Žl 31(32),1-2 a Iz 44,22 (in 1 Klem 50,6-7); 1 Petr 4,8; Ez 18,23.32; 33,1; Jr 27(=50),20. Po tomto dlouhém výčtu uvádí pasáž z 1 Jan 5,16n o rozlišení hříchů, které vedou ke smrti, a těch, které ke smrti nevedou, ${ }^{35}$ a pokračuje citací Žl 1,1 a Lv 11,7-15 a různými výklady těchto míst.

331 Jan 3,14 (in Strom. I,173,6; GCS 15, 107,23n).

34 Klementova třístupňová hamartologie vychází z Aristotelovy nauky o trojím provinění (srov. Eth. Nic. 1111a21; 1134a14 nn; 1135 b9 nn; Eth. Eud. 1223a23; Rhet. 1374b6-10), k tomu srov. E. A. Clark, Clement's use of Aristotle, New York: Edwin Mellen Press 1977, s. 45-65 a V. ČERnUŠKová, „Víra, poznání, láska,“ in Klement Alexandrijský, Stromata VII, Praha: Oikúmené 2011, s. 37-39.

351 Jan 5,16-17 (in Strom. II,66,4-5; GCS 15, 148,20-24). K uvozovací formulaci srov. s. 208 výše. 
3.5 Strom. III,32,2; 42,6; 44,5 a 45,1-2 s citacemi 1 Jan $1,6-7 ; 3,3 ; 2,4$ a 2,18-19

Celkem čtyři citace Proniho listu Janova nalezneme v první části třetí knihy Strómat, kde Klement vede rozsáhlou polemiku se stoupenci sekt. Cílem této polemiky, v jejímž rámci Klement cituje a vykládá nejen Ježíšovy výroky v evangeliích a instrukce v Pavlových listech, ale i četné pasáže $\mathrm{z}$ antických tragédií, je obhájit model křesţanského manželství, které je napadáno jak ze strany stoupenců uvolněných sexuálních praktik, tak ze strany enkraticky orientovaných křestanských skupin. Do první skupiny řadí Klement vedle žáků Karpokrata a Níkoláa také stoupence Prodíkova učení, kteří, píše Klement, si „neoprávněně říkají gnostikové“ a pyšně se domnívají, „,že jsou od přirozenosti syny prvního Boha,“ “čímž omlouvají své jednání proti Zákonu. ${ }^{36}$ Proti nim Klement postupně uvádí dva novozákonní verše Jan 8,34 („Každý, kdo hřeší, je otrok “37) a Mt 5,28 („Já však pravím, nezatoužís“ ), dále nařízení Zákona proti tomu, kdo se oddal smilstvu v Nu 25,8-13, spolu s Žl 118(119),9-10 a Jr 10,2, a nakonec slova apoštola Jana: „ک̌́íkáme-li, že s ním (totiž s Bohem) ${ }^{38}$ máme společenství, a přitom chodíme ve tmě, lžeme a nečiníme pravdu. Jestliže však chodíme ve světle, jako on je ve světle, máme s ním společenství a krev Ježíše, jeho Syna, nás očištuje od hříchu.“"39 Text epištoly, který $\mathrm{v}$ druhé části hovoří o důsledku přebývání s Bohem - totiž společenství mezi sebou navzájem ( $\left.\mu \in \tau^{\prime} \dot{\alpha} \lambda \lambda \eta^{\prime} \lambda \omega \nu\right)$, Klement upravuje do podoby $\mu \in \tau$ '

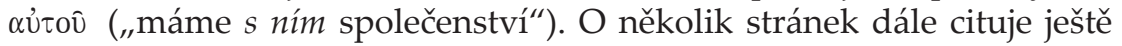
dva verše, 1 Jan 3,3 („Každý, kdo má tuto naději v Pána, posvěcuje sám sebe, takže je svatý, jako sám Bůh“) ${ }^{40}$ a 1 Jan 2,4 („Kdo říká, že poznal Pána, a nedodržuje jeho přikázání, je lhář a není v něm pravda“) ${ }^{41}$ První verš uvádí jako kontrastní ilustraci k obrazu nečisté duše těch, kdo vedou nevázaný život, druhým svou polemiku proti libertinismu uzavírá.

36 Srov. Strom. III,30,1-2 (GCS 15, 209,29-210,5). Podobně také ve Strom. II,10,2; IV,89,4 (o valentinovcích).

37 Tento verš Klement mylně uvádí jako výrok apoštola Pavla, snad pod vlivem Řím 6,16: „....bud' otročíte hříchu, a to vede ke smrti, nebo posloucháte Boha, a to vede ke spravedlnosti."

38 Doplňuje Klement.

391 Jan 1,6-7 (in Strom. III,32,2; GCS 15, 210,23-28).

401 Jan 3,3 (in Strom. III,42,6; GCS 15, 215,25n).

411 Jan 2,4 (in Strom. III,44,5; GCS 15, 216,27-29). 
S druhým extrémem, přehnanou askezí enkratitů, se náš autor vypořádává hned vzápětí. Ty, kteří pod záminkou zdrženlivosti učí, že vstupovat do manželství a plodit potomky je něco špatného, je podle Klementa namístě upozornit na následující slova apoštola Jana: „Nyní se vyskytlo mnoho antikristů; podle toho víme, že nastala poslední hodina. Vyšli z nás, ale nebyli z nás. Kdyby byli z nás, byli by s námi zůstali.“42

\subsection{Strom. IV,100,4-5 s citacemi 1 Jan 3,18-19; 4,16; 4,18 a 5,3}

Další čtyři citace se objevují ve čtvrté knize Strómat, na rozdíl od předcházejícího př́padu však následují těsně za sebou:

„Děti, nemilujme slovem a jazykem,“ “říká Jan, když nás učí dokonalosti, „ale činem a doopravdy. Z toho poznáme, že jsme z pravdy“ (1 Jan 3,18-19). Je-li Bůh láska (srov. 1 Jan 4,16), je láskou také zbožnost. „Láska nezná strach, dokonalá láska strach zaháni“" (1 Jan 4,18). „V tom je totiž láska k Bohu - že zachováváme jeho přikázání" (1 Jan 5,3). ${ }^{43}$

Tomuto místu předchází a po něm dále následuje řada citací z listů apoštola Pavla (Flp, Řím, 1 a 2 Kor, 1 Tim), jimiž Klement ilustruje osobnost gnostika. Zdá se, že Pavlovy výroky doplňuje tímto výběrem veršů z Proního listu Janova, aby je potvrdil další autoritou. Zatímco o Pavlovi hovoří standardně jako o "apoštolovi“, někdy je pro něj dokonce

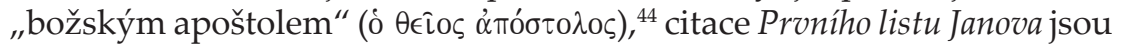
uvedeny prostým „Jan ř́ká (učí). “ ${ }^{45}$ Zatímco Pavlovy verše průběžně komentuje, Janovy skládá vedle sebe bez sebemenší poznámky.

\subsection{QDS 37,1.6 a 38,2 s citacemi 1 Jan 4,8.16; 3,14-15 a 4,18}

Své důstojné místo mají citace z Proního listu Janova naposled také v druhé části homilie Quis dives salvetur?, která je po rétorické stránce patrně nezdařilejším Klementovým dílem. Objevují se v druhé části, kte-

\footnotetext{
421 Jan 2,18-19 (in Strom. III,45,1-2; GCS 15, 217,2-5).

43 Strom. IV,100,4-5 (GCS 15, 292,24-29).

44 Srov. např. Strom. IV,101,1 (GCS 15, 293,3).

45 Strom. IV,100,4 (GCS 15, 292,25).
} 
rá již není přímo výkladem Ježíšova rozhovoru s bohatým člověkem, nýbrž oslavou lásky milosrdného Boha. ${ }^{46}$ Kromě veršů 1 Jan 4,8.16 („,Bůh je láska"), na jejichž základě Klement rozvíjí úvahu o otcovském a mateřském charakteru Boží lásky, kterou má křest’an napodobovat, ${ }^{47}$ uvádí kvưli kontrastu striktní Janovo hodnocení těch, kdo nepřijímají „něžné Boží srdce“. Slova 1 Jan 3,14-15 („kdo nemiluje, zůstává ve smrti; každý, kdo nenávidí svého bratra, je vrah") zkracuje do podoby „kdo nemi-

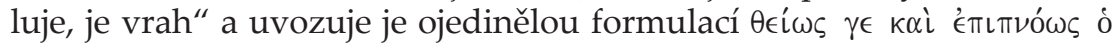

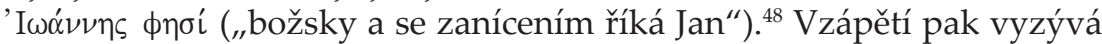
své posluchače, aby se raději vydali ke spáse „vzácnější cestou“: zřejmě nazpamět’ na tomto místě cituje velepíseň lásky z 1 Kor 13, do níž ovšem nenápadně vkládá, podobně jako tomu bylo ve Strom. IV,100,4-5, dva nepavlovské verše, 1 Petr 4,8 a 1 Jan 4,18:

Ty se však nauč onu „vzácnější cestu“ (1 Kor 12,31) ke spáse, kterou ukazuje Pavel. „Láska nehledá svi̊j prospěch," (1 Kor 13,5) ale vylévá se na bratra, po něm prahne, po něm rozumně šílí. „Láska přikryje množství hříchů“ (1 Petr 4,8), "dokonalá láska vyhání strach“ (1 Jan 4,18). „Láska se nevychloubá a není domýšlivá, nemá radost ze špatnosti, ale raduje se z pravdy. At’ se děje cokoliv, láska vydrží, láska věří, láska má naději, láska vytrvá. Láska nikdy nezanikne. Proroctví pomine, jazyky ustanou, i uzdravování bude zanecháno na zemi; zůstane však tato trojice: víra, naděje, láska, ale největší z nich je láska" (1 Kor 13,4.6-8.13). ${ }^{49}$

\subsection{Shrnutí}

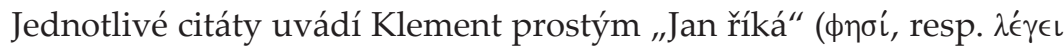

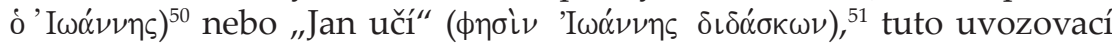
formulaci v jednom př́padě rozvádí do podoby „božsky a se zaníce-

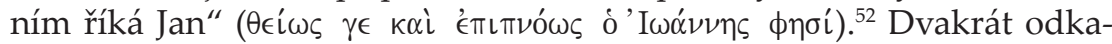

46 Někteří badatelé se domnívají, že šlo původně o samostatný text; více $\mathrm{k}$ tomu C. NARDI, "Clemente di Alessandria," in La Bibbia nell'antichità cristiana I: Da Gesù a Origene, ed. E. Norelli, Bologna: EDB, 1993, s. 372.

Srov. QDS 37,1-5 (GCS 17, 183,31-184,15).

48 Srov. QDS 37,6 (GCS 17, 184,15n.).

49 Srov. QDS 38,1-2 (GCS 17, 184,21-29).

50 Srov. Paid. III,82,1; 98,2-3 (GCS 12, 281,17 a 289,30); Strom. III,44,5 (GCS 15, 216,29).

51 Srov. Strom. IV,100,4 (GCS 15, 292,25).

52 Srov. QDS 37,6 (GCS 17, 184,15n). 


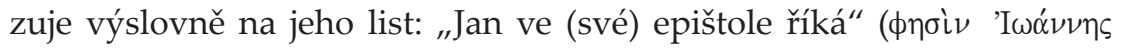

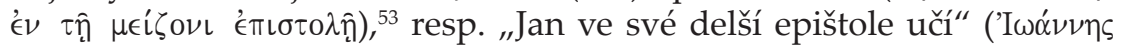

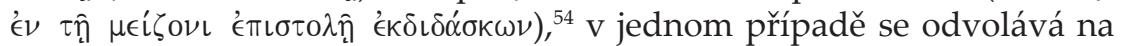

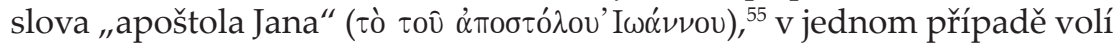
obecnou formulaci „„ríká" ( $\phi \eta \sigma i ́ v),{ }^{56}$ jíž bývají u Klementa uvozovány nejrůznější autority, včetně biblických. Vůbec nejčastější je ale případ, kdy citaci prostě vkládá do svého textu, aniž by na ni jakkoli upozornil. ${ }^{57}$ Tato skutečnost nám může činit obtíže při posuzování hranic, kdy se ještě jedná o citát a kdy už o parafrázi, popř. aluzi, nicméně ke Klementovu stylu tento způsob práce nejen s biblickým textem nerozlučně patř́i.

\section{Teologie PrVního listu Janova Jako implicitní součást KLEMENTOVA UČENÍ O KŘESŤANSKÉM GNOSTIKOVI}

Pojednáním o Klementově komentáři Proního a Druhého listu Janova v Adumbrationes a uvedením výslovných citací by naše zkoumání mohlo skončit. Tím bychom však ignorovali všechna ta místa, na nichž Klement biblický text, v našem případě Proní list Janưv, sice necituje, ale nezřídka se jím nechává inspirovat ve svých vlastních úvahách o gnostikovi. V poslední části svého článku se pokusíme na tyto souvislosti poukázat. ${ }^{58}$

53 Srov. Strom. III,32,2 (GCS 15, 210,19).

54 Srov. Strom. II,66,4-5 (GCS 15, 148,19n).

55 Srov. Strom. III,45,1-2 (GCS 15, 217,2). Jedná se spíše o výjimku; „apoštolem“ je pro Klementa především Pavel, viz zde výše 216.

56 Srov. Strom. III,42,6 (GCS 15,215,26).

57 Srov. Paid. III,82,1; Strom. I,173,6; IV,100,5 (3×); QDS 37,1 a 38,2.

58 Postupujeme podle jednotlivých motivů u Klementa, tak, jak se objevují od druhé knihy Strómat a ve spise Quis dives salvetur? Zde uvedený přehled jednotlivých veršů a jejich recepce u Klementa jistě není úplný a je třeba ho považovat za pouhé načrtnutí problematiky. K jeho obsáhnutí bude třeba mnohem důkladnější studie. Částečně jsem se toto téma pokusila zpracovat ve svém příspěvku „The Gnostic Intercessory Prayer according to Clement of Alexandria, " in The Seventh Book of the Stromateis: Proceedings of the Colloquium on Clement of Alexandria (Olomouc, October 21-23, 2010), ed. M. Havrda, V. Hušek a J. Plátová, Leiden: Brill, 2012, s. 185-198. V mnohém může dalšímu studiu této problematiky napomoci kniha F. E. Osborna, Clement of Alexandria, Cambridge: Cambridge University Press 2005, s. 107-154; 254-268. 


\section{1 "Bůh je světlo" (srov. 1 Jan 1,5)}

Spolu se slovy „Bůh je láska“59 tvoří tato metafora jakýsi implicitní základ a předpoklad Klementových úvah o gnostikovi, který se má Bohu podobat. Spíše výjimečně lze chápat metaforu světla jako aluzi na tento verš, ${ }^{60}$ většinou je však obtížné rozhodnout, zda se jedná o narážku právě na Proní list Janưv. Metafora Boha - Světla se totiž objevuje i v jiných novozákonních knihách, ${ }^{61}$ kromě toho ji však najdeme již u stoiků a u Platóna. ${ }^{62}$ Nicméně s motivem světla (a temnoty) Klement pracuje poměrně často; využívá ho jak pro metaforickou řeč o Bohu samotném, ${ }^{63}$ tak v pasážích, kde je popisováno působení Boží moci na člověka, resp. účast gnostika na Bohu. ${ }^{64}$

\section{2 "Nemilujte svět ani to, co je ve světě" $(1$ Jan 2,15)}

Dưraz na zřeknutí se věcí „,tohoto světa“ je typický pro Klementovu spiritualitu, vyznačující se poměrně př́ísnou askezí. Své nároky na manželství křestanů, ale i na celibátní život, formuluje náš autor na konci druhé a ve třetí knize Strómat, v homilii QDS se zase zabývá křestanským postojem k majetku. Obecněji pak tuto stránku svého učení vyjadřuje ve formě osobní modlitby v závěru čtvrté knihy:

Odpoutám se od žádostivosti pro sblížení s tebou, ${ }^{65}$ Pane. Stvořený řád je krásný, vše je uspořádáno dobře a nic nevzniká bezdůvodně. Musím zůstat tam, kde jde o tvou věc, Všemohoucí, a budu-li zde, jsem u tebe. Ale nechci být na ničem závis-

59 Srov. 1 Jan 4,8.16 (in Strom. IV,113,4; V,13,1; GCS 15, 298,8n; 334,17n).

60 Srov. např. Strom. V,100,4 (GCS 15, 393,2).

61 Srov. např. Jan 1,4 n a 1 Tim $6,16$.

62 Srov. např. Stoicorum veterum fragmenta (ed. Arnim) I,120.146 (Zenón); I,99.102.157; II,421-423 a Platón, Resp. VI,507b-509d (podobenství o slunci), Resp. VII,514a-517a (podobenství o jeskyni).

63 Srov. Strom. VI,32,4; 75,2 (GCS 15, 447,11 a 469,8n); Strom. VII,5,5; Ecl. proph. 21 (GCS $17,6,1$ a $142,21 n$.).

64 Srov. Protr. 2,3; 77,3; 88,2 (GCS 12, 4,9-12; 59,26-30; 65,25-27); Strom. III,44,3; VI,104,1; 105,1 (GCS 15, 216,19n; 484,14-19; 485,1); VII,37,4.6; 57,5; 79,5; Ecl. proph. 5,3; 33,1; 56,4 (GCS 17, 29,7-15; 42,15; 56,29; 138,17-19; 147,9-11; 153,11n).

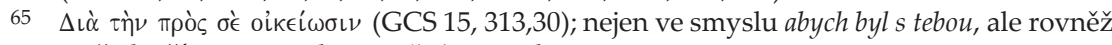
a především ve smyslu protože jsem s tebou. 
lý, abych se s tebou mohl sblížit; chci si vystačit s málem a konat tvou spravedlivou volbu mezi tím, co je krásné a co se tomu jen podobá. ${ }^{66}$

Odstup od pozemských záležitostí, vyjádřený v této modlitbě pomocí homérské formulace jakožto "odpoutanost od žádostivosti“ ( $\alpha$ ủ $\dot{\alpha} \rho$

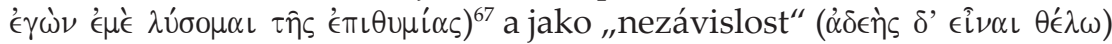
není výrazem pohrdání světem, ale výsledkem rozumné volby člověka, který na základě poznání Boha pochopil, že o Boží věci jde právě zde, $\mathrm{v}$ tomto stvořeném světě. Podobnost $\mathrm{s}$ Proním listem Janovým je přitom nápadná:

Nemilujte svět ani to, co je ve světě. Miluje-li kdo svět, láska Otcova v něm není.

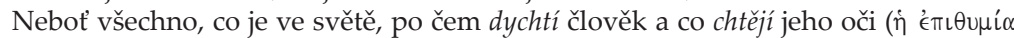

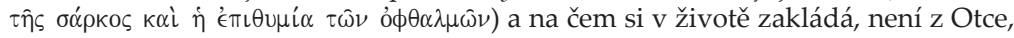

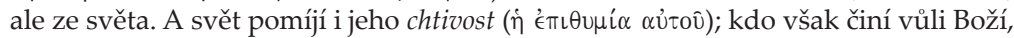
zůstává na věky. ${ }^{6}$

\section{3 „Láska vyhání strach" (1 Jan 4,18)}

Slova výše citované modlitby však ukazují na další důležitý aspekt Klementovy spirituality. Zřeknutí se špatného jednání je pouze prvním stupněm duchovního vzestupu, který směřuje $\mathrm{k}$ připodobnění Bohu a vrcholí napodobením samotného božského jednání. ${ }^{69}$ Názorným příkladem tohoto dvoustupňového vývoje je podle Klementa Ježíšova věta adresovaná bohatému mladíkovi: první negativní polovina verše (prodej vše, co máš) odpovídá prvnímu stupni (zřeknutí se), druhá polovina (dej to chudým) odpovídá stupni druhému (konání dobra) $\cdot^{70} \mathrm{~V}$ podobném smyslu chápe Klement 1 Jan 4,18: „V lásce není strach; dokonalá láska strach zahání, vždyt’ strach působí muka, a kdo se bojí, nedošel

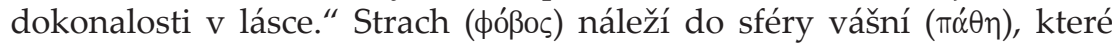
v životě křestana, jenž nechce ustrnout na prvním stupni víry, nemají místo. Stoický ideál apatheia (svobody od vášní) je leitmotivem veškeré Klementovy etiky, náš autor ho využívá i pro vysvětlení biblických me-

66 Strom. IV,148,2 (GCS 15, 313,29-314,5; překl. V. Černuškové).

67 Srov. Homér, Ilias X,378.

681 Jan 2,15-17.

69 Srov. Strom. IV,135,1.4; 137,1; VI,60,2-3; 103,2-4; 164,2 (GCS 15, 308,5-20.33nn; 462,8-15; $483,22-484,3 ; 516,16-21)$.

70 Srov. Strom. IV,28,6-29,2 (s citací Mt 19,21; GCS 15, 260,25-261,7). 
tafor, jako je kupř. „,čistota srdce“. Osvobodit se od strachu však nestačí; strach musí být vystřídán láskou. Ačkoli Klement zmíněný Janův verš doslova cituje pouze na dvou místech (Strom. IV,100,5 a QDS 38,1), zdá se, že se tento motiv neustále vrací. Na více místech svého díla upozorňuje své žáky, kteří aspirují stát se pravými gnostiky, že dokonalosti po vzoru Pána lze dosáhnout pouze takovým projevováním dobra, jež není vynuceno strachem ani podníceno odměnou (takový postoj křest’anovi nepř́ísluší), ale svobodně voleno pro dobro samotné a vedeno pravou, tedy nezištnou láskou. ${ }^{71}$ Strach z Božího soudu musí dříve nebo později ustoupit lásce, která charakterizuje dospělou víru toho, kdo již má o Bohu hlubší poznání. V tomto smyslu tedy „láska vyhání strach.“

\section{4 „Jaký je On, takoví jsme i my v tomto světě" (1 Jan 4,17)}

Připodobnění Bohu, pro něž Klement s oblibou užívá formulaci

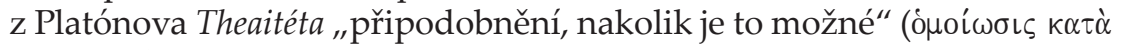

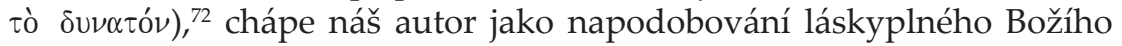
jednání v tomto světě: „Také my jsme poznali lásku,“ “ríká Jan, „kterou Bůh má $\mathrm{k}$ nám, a věříme $\mathrm{v}$ ni. Bůh je láska, a kdo zůstává v lásce, zůstává $\mathrm{v}$ Bohu a Bůh $\mathrm{v}$ něm. $\mathrm{V}$ tom jeho láska $\mathrm{k}$ nám dosáhla cíle, že máme plnou jistotu pro den soudu - nebot’ jaký je on, takoví jsme i my v tomto světě" (1 Jan 4,16-17). I když ani tyto tyto verše Klement nikde necituje, zdá se, že v posledku vyjadřují to, co ve svých Strómatech předkládá jako trojí úkol (resp. zdatnost) pravého gnostika, totiž toho, kdo poznal Boží lásku. Jeho trojí zdatnost odpovídá zdatnostem Boha, který „pozoruje, činí dobro a vychovává, “73 a Klement ji charakterizuje jako nazírání (tj. de facto přebývání v lásce) a následné napodobování Božího jednání ve světě: konání toho, co říká Slovo a vedení lidí k dobru. ${ }^{74}$ Klementova láska je př́mým důsledkem gnostikova poznání, jehož theoria je tak nerozlučně

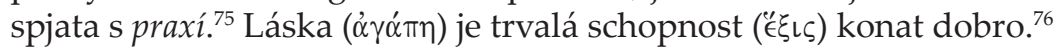

71 Srov. Strom. II,53,2-5 (GCS 15, 142,2-13); VII,46,3; 73,5 (GCS 17, 34,24-26; 52,10-14).

72 Srov. Platón, Tht. 176b; výslovně citováno např. ve Strom. II,131,5; 133,3; 136,6 (GCS 15, 185,23n; 186,17n; 188,20n); VII,3,6 (GCS 17, 5,2n) aj.

73 Srov. Strom. II,5,5 (GCS 15, 115,25n).

74 Srov. Strom. II,46,1 (GCS 15, 137,14-17); VII,4,2 a 13,2 (GCS 17, 5,5-9; 10,16-22).

75 Srov. např. Strom. I,166,2-3; II,47,4; IV,39,1-2; 49,7 s citací Řím 15,14 (GCS 15, 104,1-6; 138,8-14; 265,25-29; 271,10-13); VII,102,2; QDS 27,3-28,1 (GCS 17, 72,7n; 178,5-20).

76 Srov. Strom. II,102,2; IV,29,2; 100,4; 137,1; VI,60,3; 73,5; 103,2.4 (GCS 15, 169,1-5; 261,3-7; 292,24-26; 308,33-309,6; 462,11-15; 468,22-24; 483,22-25; 484,1-3); VII,80,1 (GCS 17, 


\section{5 „Máme v něho pevnou di̊věru, že nás slyší, kdykoliv o něco požádáme ve shodě s jeho vi̊lí" $(1 \mathrm{Jan} 5,14)$}

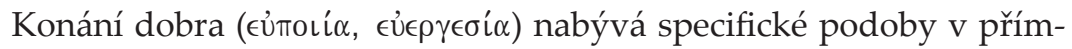
luvné modlitbě za druhé, ${ }^{77}$ jejímž vzorem je Ježíšova velekněžská modlitba v 17. kapitole Janova evangelia. ${ }^{78}$ Klement je přesvědčen, že modlitba opravdového gnostika je $v \check{z} d y$ vyslyšena, ${ }^{79}$ a to hned $\mathrm{z}$ několika důvodů. Předně modlitbu chápe náš autor jako důvěrný rozhovor, pobývání

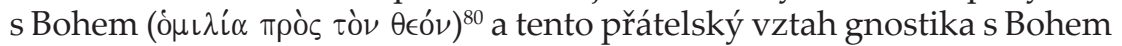
mu zaručuje vyslyšení proseb při pouhém pomyšlení. ${ }^{81}$ Plodem gnostikova přebývání u Boha je dále schopnost přesnějšího chápání, které zahrnuje také znalost toho, co Bůh chce. ${ }^{82}$ Rozdíl oproti postoji prostě věřícího, který Boží vůli naplňuje jako pouhý služebník vykonávající Pánovy př́kazy, spočívá v tom, že gnostik ví, co činí (a chce činit) jeho Pán, který již není Pánem, ale jeho př́telem. ${ }^{83}$ Díky znalosti Boha a jeho vůle má gnostik dokonce jistou prorockou schopnost. ${ }^{84}$ Šance na vyslyšení prosby je tedy veliká v prvé řadě z toho důvodu, že Bůh neodmítne toho, kdo je mu blízký, ${ }^{85}$ a dále kvůli shodě záměru prosícího a dávajícího, jak to ostatně vyplývá z 1 Jan 5,14: „Máme v něho pevnou důvěru, že nás slyší, kdykoliv o něco požádáme ve shodě s jeho vưlí."

Svého vrcholu dochází gnostické připodobnění Bohu v okamžiku, kdy gnostik odpouští svým nepřátelům a vyprošuje jim v modlitbě dobro. Jako ten, kdo má skutečné vědění, se sklání před všemi lidmi jakožto Božím stvořením a má respekt i k Spasitelovu budoucímu pưsobení: pro své poznání milosrdné Boží lásky a pro své připodobnění dobrotě Boží prozřetelnosti totiž gnostik chápe, že z nynějšího nepřítele se může stát

\section{7,6-10) aj.}

Srov. Jan 17,1-10 a Strom. VII,41,6-7 (GCS 17, 31,18-24).

Srov. Strom. VII,41,3-4; 44,1-2.5; 73,1.3 (GCS 17, 31,7-15; 33,6-11.16-20; 52,21-30).

Srov. Strom. VII,39,6 a 42,1 (GCS 17, 30,15n; 31,26).

Srov. Strom. VII,37,4; 43,2.5; 49,7 (GCS 17, 29,7-9; 32,20-23.29-32; 37,12-16).

Srov. Strom. VII,60,3 (GCS 17, 44,6n).

Srov. Strom. VII,78,4-79,1 (GCS 17, 55,31-5617) a Jan 15,15 („Už vás nenazývám služebníky, protože služebník neví, co činí jeho pán. Nazval jsem vás přáteli, nebot jsem vám dal poznat všechno, co jsem slyšel od svého Otce“). Srov. také 1 Jan 3,2 („nyní jste děti Božíi”).

84 Strom. VI,61,1; 70,4; 76,4-77,1; 78,6; 92,3 s citací Mdr 8,8 (GCS 15, 462,18-24; 467,3-6; 469,28-470,3; 471,1-4; 478,10-13); VII,79,2-4 (GCS 17, 56,17-28). 
věřící, což mu dovoluje vidět v něm již ted' potenciálního Božího přítele. ${ }^{86}$

\section{6 "A tak i my jsme povinni položit život za své bratry" (1 Jan 3,16)}

Soucitná, ale i vytrvalá Boží láska je předložena alexandrijským křestanům jako př́íklad hodný následování v homilii Quis dives salvetur?, kde je Proní list Janův třikrát výslovně citován. ${ }^{87}$ Vrcholem celého kázání je exemplum ze života samotného apoštola Jana. Zdá se, že Klementovi velmi záleží na tom, aby čtenář věděl, že se nejedná o pouhou „bájnou historku“" nýbrž o "skutečnou událost", 88 jejíž vyprávění dosahuje až k prvním Ježíšovým učedníkům. ${ }^{89}$ Dojemný příběh o Janově pastoračním působení $\mathrm{v}$ Efesu, který bývá považován za součást nějaké rané tradice, snad paralelní s tou, která se stala základem apokryfních Skutků Janových, a která se posléze dostala až do středověké Legendy aurey, ${ }^{90}$ vrcholí líčením druhého obrácení mladého lupiče: apoštolova vytrvalost v modlitbách za jeho záchranu i odvážný duch, jenž ho po vzoru Ježíše Krista vede k prohlášení: „,bude-li to třeba, rád na sebe vezmu tvoji smrt, “91 má i v tomto př́ipadě zcela nepochybnou paralelu v Proním listu Janově: „Podle toho jsme poznali, co je láska, že on za nás položil život. A tak i my jsme povinni položit život za své bratry. ${ }^{492}$

V některých případech se jeví obtížné posoudit, zda se Klement nechal inspirovat Proním listem Janovým nebo janovskými spisy Nového zákona obecně; v některých případech se jedná o velmi obecné motivy, přítomné také v jiných biblických knihách a rovněž u Platóna. Toto zjištění

86 Srov. Strom. VII,86,1n.5 (GCS 17, 61,20-26; 61,31-62,4).

87 Srov. QDS 37-38 (GCS 17, 183,31-185,6); viz zde s. 216-217.

88 Srov. QDS 42,1 (GCS 17, 188,1n).

89 Ke Klementově zvláštní úctě k tomuto apoštolovi viz E. JunoD, „Un écho d'un controverse autour de la pénitence: l'histoire de l'apotre Jean et du chef des brigands chez Clément d'Alexandrie (QDS 42,1-15),“ RHPhR 60 (1980): 153-160.

90 K dalšímu osudu této raně křestanské tradice o apoštolu Janovi viz C. NARDI, „La fortuna del Quis dives salvetur: Il racconto del giovane brigante," in Clemente Alessandrino, Quale ricco si salva? Il cristiano e l'economia, Roma: Borla 1991, s. 117-172.

91 QDS 42,13 (GCS 17, 190,5-7); srov. také zástupný charakter gnostikovy modlitby ve Strom. VII,80,1 (GCS 17, 57,7-10).

921 Jan 3,16. 
do jisté míry znemožňuje určit, kdo nebo co je Klementovou primární inspirací, je třeba si však být vědom toho, že tato potíž provázející interpretátory Klementova díla, je pro našeho autora naprosto typická a dovolujeme si tvrdit, že ze strany samotného Klementa dokonce záměrná.

\section{ZÁvĚR}

Ačkoli tento článek nemohl postihnout problematiku Klementovy recepce Janových listů vyčerpávajícím způsobem, přináší již ted' zajímavé dílčí závěry:

1. Klement znal jistě Proní a Druhý list Janưv, pro znalost Třetího listu Janova nemáme do̊kazy, ale nevylučujeme ji. Formulace, jimiž Klement jednotlivé citace uvádí, ukazují, že o Janově autorství nepochybuje. Proní list Janưv Klement chápe jako dopis apoštola (resp. presbytera prvotní církve), který byl přímo účasten Ježíšova pozemského života a který sepsal čtvrté, tzv. „duchovní“ evangelium (srov. Hypotypóseis, zl. 8). Jeho autorita je pro Klementa veliká: je učitelem duchovního života.

2. Janův odkaz Klementovi rozhodně není cizí. Kromě Listů apoštola Jana se odvolává na nekanonickou tradici, která snad mohla být pramenem apokryfních Skutků Janových. V Adumbrationes se odvolává na svědectví apoštola Jana, který se „dotýkal Pánova těla“, v QDS pak vzpomíná moudrého laskavého starce, jehož nasazení pro záchranu mladého hříšníka dává za vzor svým alexandrijským souvěrcům. Tuto nám již ne zcela zřejmou tradici Klement, jak se zdá, rád a vděčně přijímá.

3. Klementovy poznámky k Pronímu a Druhému listu Janovu, dochované v latinském překladu z 6. století pod názvem Adumbrationes, jsou patrně prvním křestanským komentářem $\mathrm{k}$ Janovým listům vůbec.

4. Přímé citace z Proního listu Janova nejsou v porovnání s ostatními biblickými knihami časté, ale často se objevují na exponovaných místech, typicky v závěru knihy (viz závěrečné pasáže Paidagóga, závěr Strom. I nebo závěr homilie Quis dives salvetur?).

5. Citace z Proního listu Janova se často objevují v bezprostřední blízkosti dalších biblických autorit; na rozdíl od citací Pavlových listů je však Klement nikdy nemá potřebu vysvětlovat nebo obhajovat. Uvádí je prostě jako jednu z mnoha, nebo dokonce jako poslední rozhodující autoritu, která potvrzuje jeho vlastní výklad, popř. ozřejmuje smysl jiných biblic- 
kých míst. Za povšimnutí stojí rovněž časté spojení Proního listu Janova s veršem 1 Petr 4,8 (v QDS 38,1; Strom. I 173,6 a II 65,1-66,5).

6. Nezávisle na výslovných citacích se jeví nejvýraznější vliv Proního listu Janova v Klementově koncepci křest’anského gnostika, který napodobuje Boží lásku ke všem lidem. Jedná se o tyto motivy: Bůh Světlo a Bůh Láska; nebýt ze světa, ale být ve světě; napodobování Boha; láska vyhání strach; odvaha položit život za nepřátele; gnostik chápající a jednající podle vůle Boží.

\section{Clemens Alexandrinus Epistularum Ioannis apostoli interpres}

Keywords: Clement of Alexandria; First Epistle of John; Patristic Exegesis

Abstract: The paper highlights the importance of the Johannine writings, particularly the First Epistle of John, in Clement of Alexandria's thinking. In the introduction, it asks whether Clement knew all three of John's Epistles. It initially deals with Clement's commentary on 1 and 2 John, which was part of his lost writing Hypotyposes, and whose Latin translation was carried out by Cassiodorus Senator in the 6th century. It consequently identifies 16 explicit citations in Clement's other works (Paedagogus, Stromata and Quis dives salvetur?) and finally highlights the importance of certain verses $(1: 5 ; 2: 15 ; 3: 16 ; 4: 8.16-18 ; 5: 14)$ for the author's concept of the Christian gnostic.

Mgr. Jana Plátová, Ph.D.

Katedra biblických věd

CMTF UP

Univerzitní 22

77111 Olomouc 